UDK: 373.2.014:329.12

Original scientific paper

\title{
PEDAGOGICAL LIBERALISM
}

\section{Željka Pintar}

Kindergarten Kustošija Zagreb

Republic ofCroatia

zeljka.pint@gmail.com 


\section{ABSTRACT}

This paper deals with the characteristics of the modern pedagogical paradigm, especially that of early and preschool education which emerged in the social context of liberal ideology. In order to better understand the educational model it promotes, the introductory part of the paper discusses the basic principles and starting points of the liberal social concept. The paper problematizes the diversity of the liberal conception of upbringing and education in relation to advocacy of the socialist social concept. The concept of self-regulated learning in the context of upbringing and education of an early and preschool child is observed. Common syntagms of the modern educational paradigm related to early and preschool education, such as the one about space as a third educator, are problematized. In this context, it is considered who or what constitutes basic pedagogical capital. The role of educators in the educational process, as well as the importance of adults in education in general are considered, and from this position the process of self-regulated learning is observed. The importance of selfobservation in the current educational paradigm and recognition of the need for its ideological improvement in order to adequately contribute to children's upbringing and education is pointed out.

Key words: liberalism, modern educational paradigm, self-regulated learning. 


\section{INTRODUCTION}

The modern educational paradigm is formed in the context of modern society of a liberal-social, capitalist-economic orientation. Liberalism has overcome opposing ideologies, the communist and the fascist, and interprets itself as a natural form of life. It refers to natural rights that start from the perceived zero position of humans, their pure nature. The liberal starting point is based on a vision of an imaginary pre-social state, when individual man was in a natural state, unencumbered by the constraints of social ties. The man of liberalism is free and self-directed, free from any constraints of culture and social relations. The social contract regulates the rationally calculated relationship of a free individual with the collective. The purpose of social contract is to protect the individual's natural rights - the right to life, property and happiness.

The principle of naturalness invoked by liberalism has historically been expected, given that any order on which social order rests tends to be self-explained as a necessary, objective reality created by either great gods or natural laws (Harari, 2015). The attitude according to which the liberal system is based on the regulation of social life arising from man's natural state and belief in the normality of liberalism, points to the need for liberalization, not only of the state and economy, but also of the whole society - ethics, public morality, family, church, schools, universities (Legutko, 2019). What cannot be characterized as liberal is interpreted as outdated, staring at the past, uncreative. Some authors argue that the values of liberalism, as the most rational political order, are of general importance (Penda, 2007). Liberalism promotes a scientific approach in all spheres of life and explains how the rational individual moves away from a tribalistic, magical, uncritical view of the world (Penda, 2007). In this sense, only an uninformed ignoramus or fanatic can doubt the ideology of liberalism and deny that, for example, family should be liberalized and parental authority, like any other, neutralized (Legutko, 2019).

An autonomous, self-legislating individual, with the right to individual selfdetermination, is the key idea of liberal tradition (Brčić, 2006). The center of the liberal approach are individuals responsible for their own actions and deeds. They are independent creators and organizers of their own existence. A liberal individual is called to overcome the constraints of culture, upbringing and other obstacles to human self-legislation. Any possible influence on man "from elsewhere" is denied. Apart from cultural independence, humans are also transcendentally independent; they independently progress towards moral perfection (Perović, 2017). Men of liberalism hold morality in self-control and self-attachment to their own mind and reject any idea of influence from anyone outside or above them (Perović, 2017). 
The proposed notion of the relationship between an individual and the community in a liberal context is significant. As stated, liberal ideology proposes the role of the state as a protector of individuals' natural rights which inalienably belong to them. According to the liberal theory, citizenship is a set of free and autonomous individuals who follow their rational self-interests in society in conditions of market competition and minimal social protection of the vulnerable and those in need (Vujčić, 2001). The American Declaration on the Rights and Duties of Man (1948) notes that an individual's rights do not derive from or belong to the state, but are based on attributes of the individual's personality (Spajić-Vrkaš et al., 2005).

Hobbes, the father of modern political science, believes that a man in prepolitical conditions, in the so-called natural state, is lonely and unsocial, driven by instinct for self-preservation and need for power (Pavlović, 2006). In this imaginary concept, natural right and natural laws rule. Natural right is understood as men's freedom to use their own powers aimed at maintaining their own nature and life (Pavlović, 2006). In their natural state, free individuals are at war with each other due to the struggle for same resources, and in order to end that struggle, they transfer part of their rights to the state by agreement, voluntarily. At the same time, according to Locke's theory of individualist liberalism, individuals do not assign their rights to the state, but refer it to the task of protecting their interests (Croatian encyclopaedia John Locke).

Liberal community is aimed at emphasizing the importance of individuals' rights, without emphasizing their obligations in the collective. Referral to duties of an individual towards the community is considered an anti-liberal, even totalitarian principle. Some Western authors believe that efforts to connect citizens' rights and duties could lead to the devaluation of the very idea of human rights (Spajić-Vrkaš, 2005). However, Article 29 of the Universal Declaration of Human Rights states that an individual has obligations only to the community in which independent and full development of his personality is possible. Some authors note that this provision was added under pressure from Asian, Latin American and communist countries which, due to the influence of culture, religion or ideology, emphasize duties individuals have towards their community (Spajić-Vrkaš, 2005). It is noticeable that modern individuals still accept the suggestion of the liberal concept, showing disinterest, indifference, and ignorance of political processes in the collective that are related to issues of the common good (Mesarić, 2001). Precisely because of the observed reduced interest of Western Europeans in democratic processes at the end of the 20th century in international and European agreements, the issue of individual responsibility towards the community is questioned in a more engaged, 
but still very cautious way (Spajić-Vrkaš, 2005). At the same time, responsibility is understood as freedom of an individual to choose according to their beliefs, with the obligation not to endanger the freedom of others (Spajić-Vrkaš, 2005).

The liberal anthropological picture is different from that of the ancient and Christian ones. Protoliberals Hobbes and Locke, in spite all their differences, do not conceive human beings as beings of the community, but view them as free and independent individuals, uninformed to others (Deneen, 2020). By the liberally interpreted human nature, they are autonomous and reluctant to establish relationships with others (Deneen, 2020). In doing so, liberalism invokes the advocacy of rationality and scientificity, evoking Bacon's thesis that knowledge is power. Above all, it presents how its idea is based on natural laws in natural, pre-social state, and speaking of man's nature, it establishes the concept of natural rights.

But, on what basis does the liberal notion of man appropriate the right to call itself natural?

By studying the human evolutionary line, assumptions are made that Homonoids, after having been separated from a common ancestor of man and ape, gradually evolved into a modern man, Homo Sapiens (Barčić, 1991). Homonoids are thought to have been half-apes-half-humans. With development of genetics, the belief has grown that, according to the degree of genetic matching, anthropoid monkeys are man's closest relatives (Kokić, 2019). Primatologists claim that chimpanzees, like humans, possess a high level of social and psychological flexibility (Waal, 2001). Their social organization, and the way of establishing relationships in groups of apes (chimpanzees and bonobo monkeys) is considered, as they belong to the same hominoid branch of the evolutionary tree as human species (Waal, 2001). Their study shows that chimpanzees find it difficult to get out of the group they belong to.

Evolutionary development of man's two-legged gait has narrowed woman's hips and birth canal. Human cubs are born prematurely, with underdeveloped vital organs, helpless and dependent on the elderly for years in terms of food, protection, and learning (Harari, 2015). It is explained that for all more developed mammals the time of intrauterine development depends on the stage of development, so comparative analysis shows that humans should be carried for 21-22 months (Senković, 2007). The first year of a child's life is therefore also called the embryonic extra-uterine year in which man, unlike other mammals that are formed in the mother's womb, is formed in communication with the environment (Senković, 2007). Such biological characteristics significantly contribute to the development of human social abilities. 
In pre-agrarian societies, people lived in gangs, and loneliness and privacy were rare. It is believed that it was the ability to cooperate within and between hordes of Homo Sapiens that gave a key advantage over other human species (Harari, 2015).

Authors conclude that in the human species, composed of individuals owning their free will, one can occasionally find a hermit who opts for solitude, but no one is found who consciously decides to become a social being because we cannot choose to become what we naturally already are (Waal, 2001).

Related conclusions can also be reached if man's divine nature is observed. In biblical anthropology, we find man as being constitutively directed to communion with God and other people. In the creation of a man, his solitude is presented as loneliness, a state close to death, which is resolved by God's creation of a woman (Pavlić, Vlahović, 2017).

According to Kant, man is an autonomous subject capable of acting independently in accordance with moral principles. The relationship between man and God takes place in a closed circle of autonomous mind and idea of good. The mind, through its moral principles, produces the notion of God (Perović, 2017). However, authors like Levinas, as opposed to Kant's rational ethics of duty, emphasize the value of the Other as the purpose of human action. Levinas's ethics rests on the principle of responsibility for the Other. The Other is the starting point, criterion and purpose of human action, he is a neighbor, companion and interlocutor, whose closeness to man, as a moral being, is necessary (Oslić, 2001).

These biological-theological views, instead of liberal ones, are close to ancient tradition. In the ancient conception, the relationship between individuals and community was perceived as harmony. According to Aristotle, goals of the individual and the polis coincide; morally good citizens form a stable and successful political community, and the justice and wisdom of the law guarantee perfection of citizens (Senković, 2006). Liberal anthropology assumes that in his natural state a man is without culture, and social and religious norms are presented as paternalistic, ineffective, unreliable, repressive, arbitrary, and restrictive (Deneen, 2020). In ancient understanding, such a gap between human nature, culture and upbringing is unimaginable. Aristotle believes that upbringing develops an individual's virtues that imply reasonable thinking and action. It is only through upbringing that men achieve harmony with their own nature and acquire human dignity (Šanc, 1941). Premodern men do not appropriate their freedom as a right that belongs to them by birth. They are self-critical and self-demanding, they understand freedom as a result of the learning process, that is, the use of higher abilities of reason and spirit (Deneen, 2020). In contrary, modern individuals, who 
acquire their dignity by birth, can finally prove that even the simplicity of their behavior, words and ideas grow out of something noble (Legutko, 2019).

The practical realization of the idea of liberalism, and its independent individuals directed to the idea of freedom and progress, guided by instructiondare to know; the mentally oriented, rational constructors of their own truths and morals, are noticeable, among other things, in the modern destruction of men's own natural environment. Some authors point out that the global scale of ecological crisis and threat of self-destruction begin precisely in the ideological breeding ground of a perverted conception of man, human mind, nature and life (Matulić, 2006).

The focus of this paper are features and peculiarities of the pedagogical paradigm characteristic to this milieu of modern, liberal society.

\section{TRADITIONAL EDUCATIONAL PARADIGM AS CONTEMPORARY STRAWMAN}

By self-presenting its educational model, the contemporary pedagogical template, characteristic of liberal-democratic communities, tends to challenge justification of every feature and direction of the traditional one, typical of the socialist period. At the same time, the modern paradigm is often interpreted too simply and it one-sidedly presents traditional pedagogical intentions. By caricaturing the traditional educational template, it seeks to make it, like a strawman, absurd. When underestimated, the traditional educational model becomes an easier target of attack and a crucial argument for the self-glorification of modern pedagogical starting points.

The modern pedagogical paradigm, in contrast to the behaviorist-traditional one, refers to starting points of humanistic psychology. Humanistic psychology places the self-realization of an individual at the center of its theory, starting from seeing men as free, dynamic and creative beings responsible for their own destiny, which can and should influence personal growth and development, as well as the realization of the human potential (Buljubašić-Kuzmanović, Gazibara, 2015). Child's learning, in line with tendencies of humanistic psychology, is necessarily meaningful, self-initiated, self-evaluated; students learn best when they have a desire and need for knowledge. The art of how to learn is more important than a large amount of knowledge, self-evaluation is the only meaningful way of evaluating student work, feelings are just as important as facts and students learn best in an environment that does not endanger them (Buljubašić-Kuzmanović, Gazibara, 2015). 
It is noted that humanistic pedagogues will be more interested in the goal of education than in techniques; they will look at man as a unique, living psychosomatic being, and not as an organism of physical and physiological stimuli and reactions (Puljić, 1981). Humanistic psychology is obsessed with resisting manipulations of all kinds and is accompanied by the desire to realize individual qualities by reference to the individual's self-realization (Puljić, 1981).

A child who is self-realized and self-determined is instructed to take responsibility for his own development. As stated in the National Curriculum for Early and Preschool Education (2015), a child is a social entity that participates, constructs, and largely determines his/her own life and development. The justification for the adultization of a child who is attributed responsibility for his or her own developmental well-being will be discussed in particular in the context of selfregulated learning.

Ensuring freedom in the modern educational concept, especially in the preschool period, is interpreted through children's freedom to choose their own activities. If children independently choos an activity, it is assumed that they are intrinsically motivated to do so. It is noted that the activities that are initiated and organized by early and preschool children imply their active and voluntary involvement in the activity, which raises their cognitive engagement (Merry, Rogers, 2007 as cited in Slunjski, 2011). However, it is shown that the role of choice for a child's intrinsic motivation is culturally conditioned (Iyengar, Lepper, 2002 as cited in Sorić, 2014). In collectivist cultures, autonomy and independence are not essential characteristics of self-perception. In them, the possibility to chose is not understood as the satisfaction of individual desires and goals, but as a possibility of choosing options that are in accordance with standards of the group to which individuals belong. Research (Iyengar, Lepper, 2002 as cited in Sorić, 2014) in which seventh to nine-year-old American children of European and Asian descent chose one of six activities showed that "Western" children demonstrated the strongest intrinsic motivation and achievement in activities of their choice, while "Eastern" children found motivation and showed achievement in the activities their mother chose for them. The role of independent choice of activities in intrinsic motivation of children is not natural, but significantly culturally determined.

The activity which a preschool child chooses with a high level of intrinsic motivation is certainly child's play - the child chooses it, determines the length of its duration, flexibly structures the rules, decides on teammates (Šagud, 2015). Some authors claim that educational preschool curriculum focused on learning through play ensures a higher level of achievement of children compared to a directive and instructive one (Šagud, 2015). However, at the same time, it is emphasized that 
early and preschool children develop in a variety of ways and play is not the only strategy preferred by all children (Dockett, 2011 as cited in Šagud, 2015).

In choosing a child's activity, it is important to carefully consider the segment of freedom. Free choice implies a rationally thoughtful and consciously chosen act. As men are not dominantly instinctive or genetically determined creatures, their freedom is manifested in rational self-directed actions. Preschool children primarily choose their activities spontaneously, driven by emotions, or, they tend to do what they are naturally, genetically prone to. If educators' educational work is predominantly based on child's choice, and there is no balance of spontaneous and accidental children's interests and preferences and educators' directional action which encourages children to expand the domain of their interests, capabilities and preferences, it is questionable how devoted they really are to the achievement of children's freedom. When the self-elective educational model that invokes freedom is exclusively used, it actually imprisons children in the limitations of innate inclinations that they, left to themselves, find difficult to overcome. Contemporary authors note that behaviorists considered the process of upbringing and education as a planned and deliberate practice and getting used to expected models and forms of behavior (Petrović-Sočo, 2009). The traditional teacher subjected students to algorithmic actions using didactically designed materials and isolated content selected from scientific disciplines that were supposed to provoke a child's reactive learning through mental training (Petrović-Sočo, 2009).

At the same time, contemporary authors note that, for example, in learning to read and write, students need to be taught strategies related to these skills in a timely manner and shown how and when they are used (Nikčević-Milković, 2014). Specifically, it is noted that students need to develop metalinguistic awareness, and teaching strategies related to it is the key role of teachers who use modelling methods to show students how they use them themselves (Nikčević-Milković, 2014).

It is generally believed that teachers should support the development of children's cognitive strategies by instructing children to revise content when it needs to be memorized, by encouraging organization of information (looking for the most important ideas in the text or drawing mind maps) or by showing how they connect different content themselves (Pavlin Bernardić, Vizek Vidović, 2019). It is noted that subject teachers in primary schools, within their subjects, should show students how to learn a specific subject and model application of learning and memorization strategies on the content of their subject (Nikčević-Milković, 2014).

Can a teacher's teaching a child how to use cognitive strategies also be considered mental coaching? 
Behaviorists believed that the learning process could be managed from outside. Contemporary authors note that the learning process cannot be directly managed, so this process cannot be strictly controlled or unified in any segment (Slunjski, 2011). Although they do not believe in learning management, contemporary authors suggest methods that will result in the so-called, active learning of the child.

Active learning implies a constructive process in which students take personal responsibility for the process of learning (Letina, 2016). Strategies and methods that promote active learning are focused on the student's mental, emotional and psychomotor engagement (Gazibara, 2018). Appropriately, some active learning strategies are problem solving, discovery learning, teaching based on real events, topics, or problems (Gazibara, 2018). Student group work or pair work is suggested. It is noted that active learning achieves a higher degree of child's independence, application of various thought strategies and development of specific cognitive skills that enable observation of the important, analysis and comparison of information, connection with existing knowledge and critical assessment of their meaning (Letina, 2016). Active learning methods are considered to enable the organization and elaboration of information, which encourages deeper processing of content. Could we consider such a modern proposal for an approach to learning methods as an attempt at external learning management? Contemporary authors express how a particular method affects a child's approach to learning. Do active learning methods necessarily encourage a child's deep information processing?

Learning is, regardless of the method, a personal process. Methods depend on the content the child is getting to know. The radical separation of modern methods of active learning from traditional teaching methods is considered unjustified. Some authors state that direct teaching of children is not at all in contradiction with understanding the active construction of knowledge (Babić Irović, 2001 as cited in Palekčić, 2002). They consider it important to optimize the relationship between abstract instruction (direct teaching) and learning through discovery (knowledge construction). It is noted that it is impossible to imagine a pedagogical theory that could abandon this consensus (Palekčić, 2002).

The modern educational template assumes that the role of a traditional, directive and instructive teacher was to instruct the child to adopt the content, mostly through the technique of reproduction, and that contents which shape educational work were given considerable, too much importance. In contrast, the modern pedagogical model considers content only as means of developing competencies (Palekčić, 2014) and, instead of reproducing the material, is primarily focused on the development of critical thinking. 
However, critical thinking cannot replace the adoption of information. In order to think critically, it is necessary to form arguments that imply search for true facts from which valid conclusions are drawn. Opinion cannot replace the importance of knowing the content, and meaningless encouragement of critical thinking is impossible. In addition, contents are considered a component of the didactic triangle, which, in addition to them, consists of a student and a teacher (Varga, 2015), so it is unjustified to reduce them only to a means of developing competence.

Although liberal-democratic societies dispute the importance of (educational) content, it is exactly in them where their appreciation should be significant. Namely, in liberal democracies, it is not unimportant how public opinion is constructed whether it respects certain knowledge, information, argumentation, truthfulness, justice or rests on various variants of "uncrystallized social consciousness" (Vujčić, 2001).

Opinion without knowledge is blind, and the idea of goodness gives truth to objects of cognition and power of cognition to the one who cognizes (Šarac, 2019). It is necessary that knowledge is constructed with true content and alignment with certain values. Modern history shows how scientific rationality void of value dimensions becomes an irrational venture. It was the application of ethically crippled rational scientific methods that led to greatest wars and massacres of the 20th century (Peračković, 2016). Therefore, it is necessary that development of child's critical thinking implies precisely his / her recognition of the importance of content and guidance with clearly thought-out values.

Modern pedagogical template resents the traditional one due to excessive focus on a large range of unusable, non-functional knowledge. Humanistic psychology criticizes overemphasized intellectual education in the past at the expense of, for example, affective development (Puljić, 1981).

At the same time, the modern, humanistic pedagogical model of the knowledge society pragmatically promotes the educational development of human capital. The Declaration of Knowledge (2004) states that Croatia needs to get out of the circle of less developed countries regarding knowledge and thus prevent technological backwardness. Because of this, children from an early age should acquire basic knowledge and skills in science, technology, engineering and mathematics, as this knowledge is crucial in a technology-dependent society (Science, Education and Technology Strategy, 2014). By prioritizing the STEM area over that of the post STEM character, individuals focus on the useful truth and free themselves of the superfluous reflection of reality that can only be considered by comparison with some previous condition (Nikodem, 2004). Memory is an already dangerous 
burden and one of the main enemies of a liberal system that feeds and strengthens on human oblivion (Legutko, 2019). Proponents of the modern pedagogical model therefore speak of the need for education that opposes the dominance of books because they lead to decontextualization, of verbal lectures because they cause student passivity, of frontal teaching because it neglects differentiation (Vican, 2007). In the modern pedagogical model, true is what works, what bears fruits of action, what serves life goals - the criterion of truth is practicality, profitability and usefulness (Novalić, 2012).

Just as the purchase of machines increases productivity of a factory, humanistic education increases the production capacity of workers (Bogdanović, 2008). The comprehensive presentation of human capital is designed as a characteristic of workforce that enhances an individual's contribution to the work organization. It is concluded that, given the comprehensive characteristics, some individuals can be considered larger human capital than others (Bogdanović, 2008). A work organization needs individuals with a higher IQ, in whose heads concepts do not remain unconnected, with high emotional energies, strongly motivated and energetic in the long run, of moral capacities appropriate to a fair distribution in which no one takes more than one deserves, and is able to create a network of interrelationships (Bogdanović, 2008). It is emphasized that gifted and hardworking young people are a basic natural resource that leads to progress of the society (Declaration of Knowledge, 2004).

With this approach, humanistically comprehensive development-oriented template of education becomes an economically calculated venture to create a useful workforce.

As noted, the modern educational model traditionally reproaches the dominant orientation to the cognitive sphere of development in the traditional model. At the same time, the modern educational paradigm focuses on challenges of affective education (Buljubašić-Kuzmanović, 2015), notes the importance of relationship pedagogy (Varga, 2015) or talks about programs of Little Philosophy aimed at value education of children (Ćurko, Kragić, 2008). This shows how the modern concept of education is vague, fragmented, partial. Namely, it is unclear how children's learning could be separate from their emotions, from established relationships or values. It is problematic that a pedagogical model which invokes a cognitively unreduced approach to the child, is at the same time a disintegrated, unsystematic and superficial approach to understanding the concept of upbringing.

The modern educational template emphasizes the importance of children's autonomous self-evaluation of their own activities. At the same time, the quality of educational work of their teachers is assessed by external institutions, such as 
centers for external evaluation of education that prescribe educational standards -learning outcomes in form of competencies that students of a certain educational level should achieve. The modern pedagogical paradigm explains how this encourages teacher autonomy. However, together with the fact that it is not clear how external evaluation of teacher work would promote their independence, it is considered that such a rationalist-empiricist approach also encourages neglect of immeasurable teaching results (such as child's developed care for others, levels of resilience to stress, dedication to justice and public good in life) and in that sense is inadequate for both the teacher and child (Matanović, 2017).

\section{SELF-REGULATED LEARNING OF THE MODERN CHILD IN THE CONTEXT OF EARLY AND PRESCHOOL EDUCATION INSTITUTIONS}

Maximum privatization, reduction of state interventionism to a minimum, abolition of barriers to free circulation of goods and capital are specific laws of neoliberal capitalism (Mesarić, 2006). There is talk of rationality, efficiency and irreplaceability of unfettered operation of market laws; individuals are much more successful when their actions are governed by the "invisible hand of the market" than by the "incompetent and greedy hand of the state." Liberal stratification into the rich and the poor, according to Spencer, is a natural consequence of innate superiority of individuals - the rich are biologically more valuable, so no one, especially not the state, has the right to interfere in the way their wealth is acquired (Mesarić, 2006).

In the modern world, market relations are reflected in every social sphere, even in the context of early and preschool education institutions. Thus, in kindergarten, educators listen to interests of children (market). Accordingly, it offers self-instructive didactic stimuli by which children self-regulate their selfinitiated learning (deregulation). Self-motivated engagement of children with selfselected materials enables their learning (liberalization). As it is summed up, in the process of teaching children, it is important to take into account their (self) encouragement to act, (self) organization and (self) management of activities, their independence in action, thinking and decision making in the process of which they are (co) authors (Slunjski, 2011). Educators enable the learning process but do not manage it - the responsibility for their own learning, development and progress is on children themselves.

In the context of a liberal society, the main regulator of all relations is the market in which goods circulate freely. In kindergarten, the focus is on the space in 
which educational incentives are offered. While it is pointed out that the educator indirectly participates in the child's learning process (Slunjski, 2011), at the same time the space of the institution becomes the third educator. It is noted that offered materials in the space should encourage children to set, check, revise their own assumptions and personal ideas about a particular problem that interests them, and facilitate their communication about ideas and new knowledge with other children (Sindik, 2008). A flexible organization of space rich in material incentives encourages children's concentration, perseverance and interest, and reduces undesirable behaviors among children (Sindik, 2008). The environment provides children with a natural way of obtaining information, constructing knowledge and solving problems (Sindik, 2008). Space is an aquarium that maintains ideas, values, abilities and culture of those who live in it (Malaguzzi, 1998 as cited in Budisavljević, 2015). Often, the entire pedagogical engagement of educators is assessed precisely on the basis of appearance of the spatial-material environment in which they operate.

In a stimulating material environment, pedagogical staff encourage selfregulated learning. It is defined as a process by which students consciously plan and monitor their own cognitive, affective and behavioral processes essential for successful academic activities (Schunk, 2001 as cited in Bošnjak-Terzić, 2015) and effectively use strategies important in the learning process (Bošnjak-Terzić, 2015).

Proactive or defensive cognitive beliefs about controlling the learning process are cited as components of a complex construct of self-regulated learning; motivational beliefs - assessment self-efficacy, goal orientation, attribution of success or failure. They are an important component of self-regulated learning and motivational strategies - those that encourage the learning process or serve to protect self-esteem (Lončarić, 2014).

In the process of self-regulated learning, children activate cognitive strategies, namely those aimed at the learning content (deep or superficial cognitive processing) and those related to coping with school failure (Lončarić, 2014).

In a pedagogical paradigm that advocates space as third educator, it is important to look in more detail at certain components of self-regulated learning, such as self-efficacy.

Self-efficacy refers to a child's belief that he or she can successfully achieve the behavior needed to achieve a specific goal (Sorić, Vulić-Prtorić, 2006). It represents a construct similar to self-perception or perception of personal competence related to specific activity and situation (Sorić, Vulić-Prtorić, 2006). It is considered that children's assessment of their own abilities and expectation of certain outcomes are also important in determining the goal orientation (Lončarić, 2014). It is noted 
that self-regulation of learning is impossible without assessing self-efficacy - in order for children to regulate their behavior in accordance with a strategy that can lead them to the goal, it is necessary to evaluate their own ability to achieve the goal (Milanović-Dobrota, Radić-Šestić, 2012). If a person is convinced of his efficiency, he or she will be relatively resistant to loss of control that can occur due to difficulties and failures, and will persevere in achieving goals, while success will increase the sense of efficiency (Milanović-Dobrota, Radić-Šestić, 2012).

It is stated that assessment of self-efficacy is related to attributions of success and failure - whether children assess something as success or failure by comparing themselves with their own past results or comparing it to others, or what they attribute the outcome of the activity to (Pavičić-Takač, Varga 2011).

How do children develop an idea of their efficacy? It is noted that children's self-assessment standards are most often formed on the basis of social feedback and modelling as seen by both parents (Sorić, Vulić-Prtorić, 2006). It is emphasized that parents, as children's primary models, are an example of how they accept themselves and their children, how they, through educational procedures, model optimism and adaptive self-assessments and thus influence children's perception of self-efficacy and behaviour oriented to achievement (Sorić, Vulić-Prtorić, 2006).

Some models of self-regulation (Niemivirte, 1996), in addition to learning strategies, self-efficacy and goal orientation, also include self-esteem as a component of self-regulated learning (Nikčević-Milković et al., 2014). In doing so, self-esteem is defined simply as a positive or negative attitude towards oneself.

How does a child develop self-esteem? According to the theory of attachment, children create internal mental images or "working models" of themselves and others based on experiences in relation to parents (Bowlby, 1977 as cited in Deković, Raboteg-Šarić, 1997). A parent who positively values and provides emotional support to his child gives the child a sense of worth, and this aspect of parenting style is related to child's self-esteem, not only in childhood but also in adolescence and early adulthood (Buri, Kirchner and Walsh, 1987 as cited in Deković, RabotegŠarić, 1997). Children raised in an authoritarian style that combines a high level of warmth and understanding and a high level of parental demands for mature behavior (according to developmental tasks at a certain age) are independent, able to regulate their own behavior, emotionally adjusted, satisfied and socially responsible (Maccoby, Martin, 1983 as cited in Deković, Raboteg-Šarić, 1997).

A child's ability to regulate emotions is also important for the process of selfregulated learning. Emotions can interfere with set goals, and even be a hindrance in achieving them, so it is important that a child adopts successful strategies to influence the appearance, intensity and duration of emotional experiences. 
Emotional regulation refers to attempts by which children try to influence which emotions they will experience, how and when they will experience them and how they will express them (Burić, Sorić, Penezić, 2011). The basis of emotion regulation is precisely recognition and understanding of one's own emotional experiences with the aim of monitoring, evaluating and modifying emotional response (Gross 1988 as cited in Šandrić).

How do children acquire the ability of their emotional self-regulation? In understanding their own feelings, children need the support of an adult. When overwhelmed by the intensity of their own feelings, they need an adult who encourages them by helping them restrain those feelings (Brazeltom and Sparrow, 2008). In emotionally intense situations, children need an adult who will encourage them through communication to process information that will allow them to selfcontrol (Siegel, Bryson, 2017).

In addition to the motivational aspect, the direct role of adults is also important in the development of children's cognitive strategies. Research has been conducted on the examination of metacognitive control processes in young children. The ways in which children participate in problem solving shows that aspects of metacognitive control are directly related to task success. Such control activities are acquired by the child in interaction with parents or other adults during adolescence (Browder, 1993 as cited in Gojkov, 2009).

During education, teachers should know about the motivational and cognitive strategies and beliefs that their students use (Lončarić, 2014). It is suggested that teachers should tailor messages to different groups of students in order to encourage their proactive self-regulation of learning. Gifted and intellectually above-average students who show learning difficulties should be worth of investing effort because they often have an implicit theory of intelligence which assumes that only incompetent students have to work hard. It is important to emphasize to them that investing effort does not mean a lack of intelligence. On the other hand, it is important to direct average, anxious students on the use of strategies of elaboration, connection, transformation, and critical thinking, and it is important to encourage them to seek help from others without feeling threatened or less valuable (Lončarić, 2014).

In the context of self-regulated learning, the importance of class norms and classroom climate is emphasized. The aspect of classroom climate, such as teacher's warmth and enthusiasm, respect for all students, is important in the student's perception of various situations (Lončarić, 2014). In classroom, as in other social situations, children are involved in a social system that provides them with a variety of opportunities and constraints that affect children behaviour. If children are not 
aware of them, they will be less able to function well in the classroom (Lončarić, 2014).

Although the modern pedagogical template suggests children's selfresponsibility in the self-regulated learning process, and the paradigm of early and preschool education suggests respect for space as a developmental regulator of the individual, it seems that without personal dispositions in which children participate in their activities and which they significantly improve through social relationships, materials remain only a potential development tool. In other words, from the preschool period of upbringing and education of a child without social capital, the material one represents only a likely, non-crucial development resource.

\section{CONCLUSION}

After World War II, the emergence of Dadaists in art changed the approach to science $\nabla$ in pursuit of freedom and establishment of an adult man who can live without authority, there was a fall to absolutism of scientific epistemology with a desire to destroy it and create a space of relativistic theory that can correspond to the theory of free society (Afrić, 1988). Relativization of authority and criteria in all areas of human activity directs an individual to an independent, rational questioning of reality. Rationalism, empiricism, materialism and utilitarianism are basic features of a neoliberal, capitalist society in which feelings, religious experience, empathy and subconsciousness are marked as irrelevant, second-class or insignificant (Mesarić, 2006). An open society promotes scientific concept in all spheres of life because a rational individual, unaffected by irrational excitements, is worthy (Penda, 2007). Contrary to imaginary irrationality, a contemporary individual in all spheres of his life is often dominantly calculatedly self-directed.

In a liberal, rational market concept in which knowledge and science are commodified, and pedagogical relationship is commercialized, early and preschool age children's educators are seen as providers of optimal goods, educational material incentives of exemplary quality and quantity who offer a service of indirect encouragement of cognitive development through stimulus questions. The goal of the education system is to create human capital that will innovatively participate in economic benefit of a particular political community. In the pedagogical model in which space is the educator, an educator's activity tries to be rationally and empirically quantified by assessing it through the appearance of physical space, i.e. the offer of materials in it.

Space with the offer of various educational incentives is affirmed as important in neoliberal early and preschool education and, from the perspective of a modern 
pedagogical paradigm, it is interpreted as it was neglected and ignored in the traditional template of education. However, the traditional preschool educational program suggests a completely different attitude. It is precisely in the Program of educational work in kindergarten (1979) that it is emphasized that an important condition for the realization of the program is equipment in kindergarten corners. It is stated that the role of corners is extremely important in enriching the content of children's lives, especially in the field of learning about the natural and social environment. Adequately equipped and pedagogically organized corners encourage the development of children's mathematical concepts, help their moral, intellectual and aesthetic development. The Program of educational work in kindergarten $(1979,40)$ refers to equipping, completing and regularly renewing the equipment of various corners in kindergartens.

However, the traditional program also emphasizes the active role of educators as organizers, participants and observers of child's play. Contemporary research on children's play shows that children do not recognize educators as their playmates (Rajić, Petrović-Sočo, 2015).

Although the role of didactic incentives in modern educational concepts related to early and preschool children has made an advancement with regard to the importance of educators, it is important to emphasize that the way children will approach material as a means depends on their personal dispositions developed by social relations, primarily with primary caregivers. Self-perception, regulation of emotions, image of one's own possibilities, choice of goal orientation, are constructs that children acquire based on the stimulation of their primary human contacts in the immediate environment. To equate the significance of a person and means by their identical naming is quite unjustified. Affirming the importance of stimulating space by identifying it as an educator degrades men as social creatures who build the assumptions of their development in fruitful personal relationships. Calling learning self-regulated does not mean that children are self-responsible for developing predispositions in which they participate.

The modern improvement of upbringing and education is designed in various ways, including the design of the concept of relationship pedagogy. Relationship pedagogy conceptually occurs in contemporary American literature, and rests on the understanding that relationships between people take precedence over an isolated individual (Bingham, Sidorkin, 2004, as cited in Varga, 2015). It is noted that this is an educational theory that emerges in response to failed attempts to reform American schooling (Varga, 2015). It is emphasized that the main feature of relationship pedagogy is precisely the primary focus on relationships, rather than on educational processes (Varga, 2015). Proponents of this approach are interested 
in how and to what extent interpersonal relationships affect teaching and learning (Varga, 2015). Even the need for a separate reference to the fact that the educational process requires quality relationships is worrying.

Certain authors (Buljubašić-Kuzmanović, Gazibara, 2015) talk about the challenges of affective education. Education for values and the aforementioned relationship pedagogy point to the disintegration of the concept of education and its dilution into separate innovative directions. As truth with no colour of value and non-emotional learning is impossible, the question is raised about understanding education, which implies the possibility of separating emotions and values from the intellectual-cognitive sphere. However, the undeveloped upbringing, vagueness, and inconsistency of the contemporary pedagogical template in liberal societies, have the potential for its future redefinition in accordance with its own educational traditions and inherent cultural origins. 


\section{REFERENCES}

1. Afrić, V. (1988). Paul Feyerabend, Protiv metode. Revija za sociologiju, 19 (3): 363-366.

2. Barčić, B. (1991). Pojava čovjeka na zemlji. Crkva u svijetu, 26 (2-3): 207-214.

3. Bogdanović, M. (2008). Prilog teoriji ljudskog kapitala: koja svojstva radne snage treba smatrati bitnim sastavnicama ljudskog kapitala?. Ekonomija, 15: 45-81.

4. Bošnjak Terzić, B. (2015). Socijalno-kognitivni pristup samoreguliranom učenju inoga jezika. Strani jezici: časopis za primijenjenu lingvistiku, 44 (2): 129-145.

5. Brajša, P. (1993). Pedagoška komunikologija: razgovor, problemi i konflikti u školi. Zagreb: Školske novine.

6. Brazelton, T., Sparrow, J. (2008). Disciplina Brazeltonov pristup. Buševec: Ostvarenje.

7. Brčić, M. (2006). Izvori liberalnog mišljenja u filozofiji Immanuela Kanta. Filozofska istraživanja, 26 (4): 783-797.

8. Budisavljvić, T. (2015). Kako oblikovanjem okruženja razvijati suvremeni kurikulum. Dijete, vrtić, obitelj: časopis za odgoj i naobrazbu predškolske djece namijenjen stručnjacima i roditeljima, 21 (79): 26-28.

9. Buljubašić-Kuzmanović, V., Gazibara, S. (2015). Izazovi afektivnog obrazovanja. Nova prisutnost: časopis za inteletualna i duhovna pitanja, 13 (2): 213-228.

10. Burić, I., Sorić, I., Penezić, Z. (2011). Strategije emocionalne regulacije u ispitnim situacijama: Doprinosi osobina ličnosti, kognitivnih procjena i ispitnih emocija. Psihologijske teme, 20 (2): 277-298.

11. Ćurko, B., Kragić, I. (2008). Filozofija za djecu - primjer Male filozofije. Život i škola: časopis za teoriju i praksu odgoja i obrazovanja, 56 (20): 61-68.

12. Deković, M., Raboteg-Šarić, Z. (1997). Roditeljski odgojni postupci i odnosi adolescenata s vršnjacima. Društvena istraživanja: časopis za opća društvena pitanja, 6 (4-5): 427-445.

13. Deneen, P. J. (2020). Zašto liberalizam nije uspio. Zagreb: Verbum.

14. Gazibara, S. (2018). Aktivno učenje kao didaktičko-metodička paradigma suvremene nastave (doktorska disertacija). Zagreb: Filozofski fakultet Sveučilišta u Zagrebu.

15. Gojkov, G. (2009). Didaktika i metakognicija. Novi Sad: Visoka škola strukovnih studija za obrazovanje.

16. Harari, Y. N. (2015). Sapiens: kratka povjest čovječanstva. Zagreb: Fokus komunikacije.

17. HAZU (2004). Deklaracija o znanju - Hrvatska temeljena na znanju i primjeni znanja. http://novebojeznanja.hr/UserDocsImages/Dokumenti\%20i\%20publikacije/Dokumenti\%20 i\%20publikacije\%20referirani\%20u\%20SOZT-u\%20(popis\%201)/011\%20137\%20HAZU\%20 Deklaracija\%20o\%20znanju\%20-\%20Hrvatska\%20temeljena\%20na\%20znanju\%20i\%20 primjeni\%20znanja.pdf (6/3/2021)

18. Hrvatska encikolpedija Leksikografskog zavoda Miroslav Krleža. (2012). John Locke. https:// www.enciklopedija.hr/natuknica.aspx?id=36944 (6/3/2021)

19. Kokić, T. (2019). Nemogućnost hibridizacije čovjeka i antropoidnih majmuna. Obnovljni život: časopis za filozofiju i religijske znanosti, 74 (3): 321-333. 
20. Legutko, R. (2019). Demon u demokraciji - totalitarne kušnje u slobodnim društvima. Split: Verbum.

21. Letina, A. (2016). Strategije aktivnog učenja u nastavi prirode i društva. Školski vjesnik: časopis za pedagogijsku teoriju i praksu, 65 (1): 1-31.

22. Lončarić, D. (2014). Motivacija i strategije samoregulacije učenja: teorija, mjerenje, primjena. Rijeka: Učiteljski fakultet Sveučilišta u Rijeci.

23. Matanović, I. (2017). Kurikularna reforma kao oblik standardizacije obrazovanja - pedagoškodidaktička refleksija. Život i škola: časopis za teoriju i praksu odgoja i obrazovanja, LXIII (1): 1327.

24. Matulić, T. (2006). Ideja antropocentrizma u ozračju biocentričke paradigme. Socijalna ekologija: časopis za ekološku misao i sociologijska istraživanja okoline, 15 (1-2): 23-41.

25. Mesarić, M. (2001). Uloga države u tržišnom gospodarstvu s osvrtom na aktualno stanje u Hrvatskoj. Ekonomski pregled, 52 (9-10): 985-1033.

26. Mesarić, M. (2006). Dugoročna neodrživost tržišnog fudamentalizma i neoliberalnog kapitalizma. Ekonomski pregled, 57 (9-10): 603-630.

27. Milanović Dobrota, B., Radić-Šestić, M. (2012). Značajke modela samoefikasnosti u vaspitnoobrazovnom radu s adolescentima; specijalna edukacija i rehabilitacija, 11 (4): 637-655.

28. Nikčević-Milković, A., Jerković, A., Biljan, E. (2014). Povezanost komponenti samoreguliracije učenja sa školskim uspjehom i zadovoljstvom školom kod učenika osnovnoškolske dobi. Napredak: časopis za interdisciplinarna istraživanja u odgoju i obrazovanju, 154 (4): 375-398.

29. Nikodem, K. (2004). „Unutrašnji“ totalitarizam umjesto demokracije. Jesmo li osuđeni na distopiju?. Filozofska istraživanja, 24 (2): 369-384.

30. Novalić, F. (2012). Smisao istine. Filozofska istraživanja, 32 (3-4): 453-469.

31. Oslić, J. (2001). Etika Drugoga u Emmanuela Levinasa. Bogoslovska smotra, 71 (1): 17-54.

32. Palekčić, M. (2002). Konstruktivizam - nova paradigma u pedagogiji. Napredak: časopis za interdisciplinarna istraživanja u odgoju i obrazovanju, 143 (4): 403-413.

33. Palekčić, M. (2014). Kompetencije i nastava: obrazovno-politička i pedagogijska teorijska perspektiva. Pedagogijska istraživanja, 11 (1): 7-24.

34. Pavičić Takač, V., Varga, R. (2011). Učeničko tumčenje uspjeha i neuspjeha u nastavi engleskog jezika. Život i škola: časopis za teoriju i praksu odgoja i obrazovanja, LVII (26): 39-48.

35. Pavlić, R., Vlahović, M. (2017). Čovjek -Slika Božja. Teološka interpretacija i suvremeni izazovi, riječki teološki časopis, 50 (2): 359-386.

36. Pavlin Bernardić, N., Vizek Vidović, V. (2019). Određenje i modeli samoregulacije učenja. In V. Vizek Vidović, I. Marušić (Eds.), Kompetencija učiti kako učiti: teorijske osnove i istraživanja u hrvatskom kontekstu (pp. 57-70). Zagreb: Institut za društvena istraživanja u Zagrebu.

37. Pavlović, V. (2006). Značenje Hobbesovog „Levijatana“ za političku sociologiju. Hobbes kao univerzalni mislilac moderne politike. Politička misao: časopis za politologiju, 43 (1): 59-77.

38. Penda, I. A. (2007). Soroseva interpretacija Popperove znanstveno-političke teorije. Politička misao: časopis za politologiju, 44 (1): 53-65. 
39. Peračković, K. (2016). Društvena uloga znanstvenika danas. Znanstvenik kao homo economicus i homo sociologicus versus homo academicus universalis. Filozofska istraživanja, 36 (3): 581-593.

40. Perović, D. (2017). Izlazak iz samoskrivljene nezrelosti: Kant i Levinas. Filozofska istraživanja, 37 (4): 813-832.

41. Petrović-Sočo, B. (2009). Značajke suvremenog naspram tradicionalnog kurikuluma ranog odgoja. Pedagogijska istraživanja, 6 (1-2): 123-136.

42. Program odgojno-obrazovnog rada u dječjem vrtiću. (1979). Zagreb: Zavod za prosvjetno pedagošku službu SR Hrvatske.

43. Puljić, Ž. (1981). Humanistička psihologija: opis i podrijetlo. Crkva u svijetu, 16 (1): 14-29.

44. Rajić, V., Petrović-Sočo, B. (2015). Dječji doživljaj igre u predškolskoj i ranoj školskoj dobi. Školski vjesnik: časopis za pedagogijsku teoriju i praksu, 64 (4): 603-620.

45. Senković, Ž. (2006). Aristotelov odgoj za vrline. Metodički ogledi: časopis za filozofiju odgoja, 13 (2): 43-61.

46. Senković, Ž. (2007). Antropološki temelji odgoja. Život i škola: časopis za teoriju i praksu odgoja i obrazovanja, LIII (17): 62-69.

47. Siegel, D., Bryson, T. (2017): Disciplina bez drame: integrirani pristup za smirivanje kaosa i poticanje razvoja dječjeg uma, Zagreb: Planetopija.

48. Sindik, J. (2008). Poticajno okruženje i osobni prostor djece u dječjem vrtiću. Metodički obzori: časopis za odgojno-obrazovnu teoriju i praksu, 3 (5): 143-154.

49. Slunjski, E. (2011). Razvoj autonomije djeteta u procesu odgoja i obrazovanja u vrtiću. Pedagogijska istraživanja, 8 (2): 217-228.

50. Sorić, I., Vulić-Prtorić, A. (2006). Percepcija roditeljskog ponašanja, školska samoefikasnost i kauzalne atribucije u kontekstu samoregulacije učenja. Društvena istraživanja: časopis za opća društvena pitanja, 15 (4-5): 773-797.

51. Sorić, I. (2014). Samoregulacija učenja. Možemo li naučiti učiti. Jastrebarsko: Naklada Slap.

52. Spajić-Vrkaš, V., Stričević, I., Maleš, D., Matijević, M. (2005). Poučavati prava i slobode - priručnik za učitelje osnovne škole: s vježbama za razrednu nastavu. Zagreb: Filozofski fakultet Sveučilišta u Zagrebu, Istraživačko-obrazovni centar za ljudska prava i demokratsko građanstvo.

53. Šagud. M. (2015). Komunikacija odgajatelja i djece u igri i strukturiranim aktivnostima. Školski vjesnik: časopis za pedagogijsku teoriju i praksu, 64 (1): 91-111.

54. Šanc, F. (1941). Aristotel o socijalnim dužnostima. Obnovljeni život: časopis za filozofiju i religijske znanosti, 22 (1): 5-40.

55. Šarac, V. (2019). Pregled Platonova nauka o znanju. Čemu: časopis studenata filozofije, 15 (26): $10-21$.

56. Varga, R. (2015). Razvoj učeničkih socijalnih kompetencija nastavom u okviru pedagogije odnosa. Pedagogijska istraživanja, 12 (1-2): 87-101.

57. Vican, D. (2007). Znanje vrijedno znanja - znanje vrijedno poučavanja. Pedagogijska istraživanja, 4 (2): 231-237.

58. Vlada Republike Hrvatske. (2014). Strategija znanosti obrazovanja i tehnologije. https://mzo.gov. hr/UserDocsImages/dokumenti/Obrazovanje/Strategija\%20obrazovanja,\%20znanosti\%20i\%20 tehnologije.pdf (6/3/2021) 
59. Vujčić, V. (2001). Politička misao i političko obrazovanje. Politička misao: časopis za politologiju, 38 (1): 82-97.

60. Waal, F. (2001). Prirodno dobri - podrijetlo ispravnog i pogrešnog kod ljudi i drugih životinja. Zagreb: Naklada Jesenski i Turk. 


\section{PEDAGOŠKI LIBERALIZAM}

\section{SAŽETAK}

Radom se tematiziraju obilježja suvremene pedagoške paradigme, osobito one ranoga i predškolskoga odgoja i obrazovanja nastale u društvenome kontekstu liberalne ideologije. Sa svrhom boljega razumijevanja odgojno-obrazovnoga modela koji propagira, u uvodnome dijelu rada razmotrena su osnovna ishodišta i polazišta liberalnoga društvenog koncepta. Rad problematizira različitost liberalne koncepcije odgoja i obrazovanja u odnosu na zalaganja socijalističkoga društvenog koncepta. Promatra se koncept samoreguliranoga učenja u kontekstu odgoja i obrazovanja djeteta rane i predškolske dobi. Problematiziraju se uvriježene sintagme suvremene odgojno-obrazovne paradigme vezane uz rani i predškolski odgoj i obrazovanje, poput one o prostoru kao trećem odgojitelju. U tome se kontekstu razmatra tko ili što predstavlja bazični pedagoški kapital. Razmatra se uloga odgojitelja u odgojnoobrazovnome procesu, značaj odrasloga u odgoju uopće, i iz te se pozicije promatra proces samoreguliranoga učenja. Upućuje se na važnost samopromatranja aktualne odgojno-obrazovne paradigme i uviđanja potrebe njezina idejnoga unapređivanja da bi adekvatno pridonosila djetetovu odgoju i obrazovanju.

Ključne riječi: liberalizam, suvremena odgojno-obrazovna paradigma, samoregulirano učenje. 